\title{
Migration and Educational Situation in Social Geographic Area of Lapraka
}

\author{
Msc. Brunilda Osmovi-Bibe \\ High School "Arben Broci" Tirana- Albania \\ Email brunaosmovi@yahoo.com
}

Doi:10.5901/jesr.2014.v4n2p276

\begin{abstract}
Physical-geographic and social economics conditions have made Tirana too attractive for the population of different territories of our country. Eleventh unit is chosen for living by incomers due to the appropriate regional position, due to free existing areas and also lower rents ect. This is the mean reason why the population number is increased every year indicated by natural increase and migratory movements. Also in this unit, the increase of population's number is associated with numerous social and economic problems. Multiple arrivals of the population and their concentrations in the eleventh municipal unit are not associated with the establishment of educational facilities for which the locals need. Normal conditions of housing and infrastructure enhance the quality of citizen's life and thus facilitating contribution to sustainable development. Community participation in everyday activities is essential for living. Very helpful in this direction are the degree of education and training to individuals, as for the ordinary citizens and members of the community as well as the professionals. The education is the right way to stay away from the poverty, and the book is the right choice to follow this way. So the education is the main factor for a long term sustainable development. Progress in education affects the growth of the level of emancipation of society, contributes to the perfection of the powers of the active population, reduction of morbidity, mortality, and in fertility reduction coefficient. It is the duty of all levels governance to not allow the degradation of the situation to the point that people lose hope to improve their children's lives.
\end{abstract}

Keywords: Structure of the population by educational attainment, illiteracy, summer camps ect.

\section{Introduction}

Tirana of after 1990 was unprepared to face the big political, social and economical changes and it is said that Tirana is the city of big contrasts, where wealth and poverty, knowledge and ignorance, economic aid and social exclusion coexist together. Tirana is a heterogeneous city viewed in the economic, social, cultural and education point of view. Poverty, unemployment, drug, endangered children, prostitution, domestic violence, the abandonment of the elderly are obvious ever-growing problems in number, with which the local power should deal with in Tirana.

\section{Migration and educational-social situation in the socio-geographical space of Lapraka}

The favorable physical-geographical and social-economic conditions have made Tirana very much attractive for the population of various territories in our country. The physical-geographic and social-economical conditions have turned Tirana into a very attractive area for the population of various territories in our country. The socio-geographical area of Lapraka is chosen for habitation by the incomers due to its suitable regional position also due to the existence of the free lands and low rental houses. Borough no: 11, there has been a growing population from year to year affected by the natural child birth and migratory movements. The integration of the new population with the existing one in Borough no: 11 , is considered as a normal phenomenon and relatively quick for the simple fact that the incomers comprise $75 \%$ of the borough population as they are faced with the same living difficulties and they consider as the best way the facing of the situation altogether. The growing number of the population in this borough is associated with numerous economical, social and educational problems. Borough 11 has the smallest number of the educated people and post university education, the highest percentage is comprised of people who have completed secondary education. The average of the education years for the people of 25 years old and plus, according to the data of the surveys, is 9 years, whereas the average of the education years for the habitants of Tirana is 10.4 years (INSTAT 2001). From the previous studies, it has resulted that the highest the level of education is, the lowest the number of unemployed people. In those boroughs that the level of education is higher, the temporary employment is lower. According to the registration of the population and houses in 2001, it resulted that Borough 6 and 11 were the most problematic ones as far as the education years for people over 15 years old is concerned, thus being under the average level of this indicator for the city, which is higher than in other boroughs. 


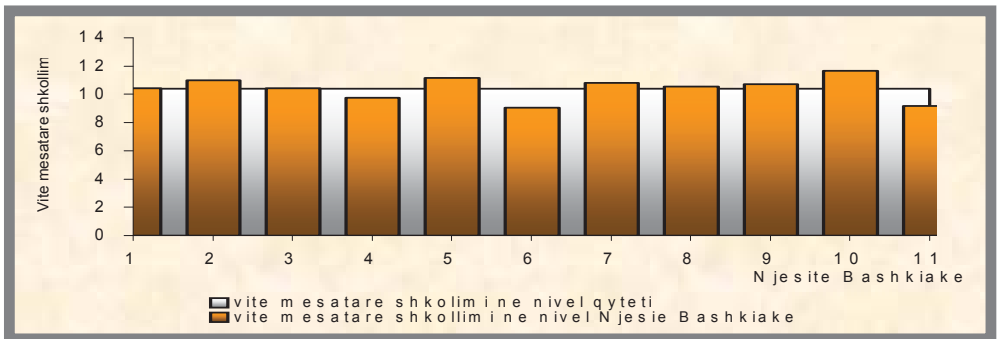

Diagram 1: The average years of education for the population over 15 years of age, according to the Boroughs in 2001: Source (INSTAT 2001)

The same boroughs are characterized by a high percentage of people with secondary education, which has definitely affected the indicator of the average years of education. From the conducted surveys, for being acquainted with the situation of 10 years later, it results that the highest percentage of the population over 25 years of age, belongs to the category of secondary education.

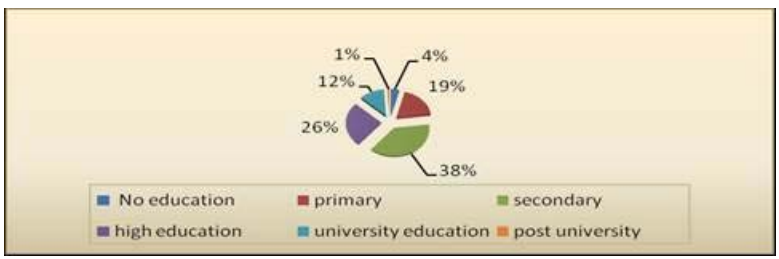

Diagram 2: Population 25 plus according to the education level in borough 11, 2011. Sources (Surveys 2011)

The massive migration of population, the creation of new urban areas, the increasing of population number, have enabled the increasing of the pupils' number from year to year, around 2000 a year (The Office of Social Care, Tirana municipality) which enables the necessity for improvement and completion of the education infrastructure for all the levels. Borough 11 has 4 nursery schools with 219 children and 4 kindergartens with 597 children. It has also 5 secondary schools with 5390 and a high school with 5390 pupils. Tirana municipality is building a new high school in "Bregu i Lumit" neighborhood, with the funds of CEB loan. Currently, almost all the buildings of nurseries and kindergartens in this borough have undergone rehabilitation and have been equipped with new furniture. "Bregu i Lumit" high schools has not yet been completed and is not functional yet, whereas "Ahmet Gashi" high school has undergone an exterior rehabilitation some years ago. The school has functioned with shifts and the Hygiene Directorate asked its closure as it didn't meet the minimal conditions for the development of the teaching process. Currently, the building is undergoing a thorough reconstruction and the teaching process for the academic year 2013-2014 is being developed in neighboring schools. The only high school is "Aleks Buda", inaugurated on November 25, 2005, was a donation of the Italian government. Given that it is the only high school in the borough, it is not able to cope with the high number of pupils, it functions in shifts. The largest number of teachers that work in these schools, nurseries and kindergartens, belongs to Borough 11, but there are even teachers from other Boroughs, 9, 7, 10.

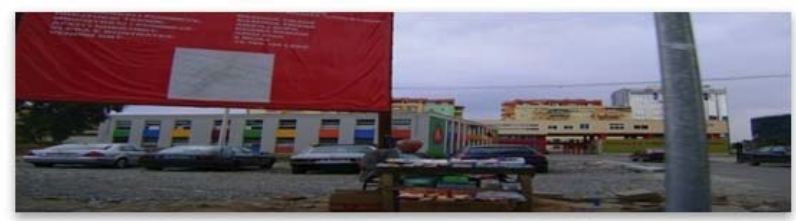

Photo 1. "Ahmet Gashi" School and "28 Nëntori" School

Nursery school 11 "The Butterflies" has limited capacitates, due to the occupation of the building by a family and by the administrator of Borough 11 herself. The only rehabilitation done to the building is only its exterior wall in 2002. The main problem encountered in the borough's nursery schools is the qualification of the educators, where a best part of whom have not the relevant education which is the high school of Medicine for Nursing. 
Char 1. Education Infrastructure of borough 11

\begin{tabular}{|c|c|c|c|c|c|c|c|}
\hline \multirow{20}{*}{ 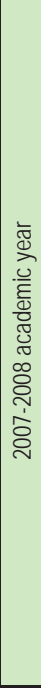 } & $\begin{array}{l}\text { Number of education } \\
\text { institutions }\end{array}$ & Name of the object & $\begin{array}{c}\text { No. of classrooms and } \\
\text { groups gr. }\end{array}$ & $\begin{array}{c}\text { Number of } \\
\text { rooms }\end{array}$ & $\begin{array}{l}\text { Number of } \\
\text { pupils }\end{array}$ & $\begin{array}{c}\text { Number of } \\
\text { teachers }\end{array}$ & $\begin{array}{l}\text { Average Number of } \\
\text { pupils in classrooms }\end{array}$ \\
\hline & \multirow{5}{*}{4 Nursery schools } & Nurseries & 8 & 8 & 219 & 25 & 28 \\
\hline & & No. 11 & 2 & 2 & 53 & 7 & 20 \\
\hline & & \begin{tabular}{|l|} 
No. 30 \\
\end{tabular} & 3 & 3 & 96 & 10 & 20 \\
\hline & & Kodër Kamëz & 2 & 2 & 46 & 4 & 30 \\
\hline & & Bregu Lumit & 1 & 1 & 24 & 4 & 60 \\
\hline & \multirow{5}{*}{4 Kindergartens } & Kindergartens & 16 & 16 & 597 & 21 & 37 \\
\hline & & \begin{tabular}{|l|} 
No. 14 \\
\end{tabular} & 3 & 3 & 160 & 7 & 51 \\
\hline & & \begin{tabular}{|l|} 
No. 28 \\
\end{tabular} & 4 & 4 & 157 & 4 & 37 \\
\hline & & Bregu i Lumit & 5 & 5 & 150 & 5 & 31 \\
\hline & & Kodër Kamëz & 4 & 4 & 130 & 5 & 33 \\
\hline & \multirow{6}{*}{$\begin{array}{l}5 \text { Secondary schools ( } 9 \\
\text { years) }\end{array}$} & Secondary schools & 172 & 110 & 5,390 & & 32 \\
\hline & & 28 Nentori & 38 & 36 & 1,151 & 51 & 30,2 \\
\hline & & Ahmet Gashi & 30 & 20 & 909 & 42 & 31 \\
\hline & & S. Luarasi & 23 & 13 & 752 & & 32.7 \\
\hline & & \begin{tabular}{|l|} 
Isa Boletini \\
\end{tabular} & 43 & 22 & 1,469 & & 34.9 \\
\hline & & Kolë Jakova & 38 & 19 & 1,109 & & 29 \\
\hline & \multirow{3}{*}{1 High Schools } & High schools & 70 & 37 & 1,565 & & 44 \\
\hline & & A. Buda & 34 & 22 & 1,565 & 48 & 43.4 \\
\hline & & Bregu Lumit & 36 & 15 & & & \\
\hline
\end{tabular}

Source. Regional Education Directorate Tirana

Many children are exposed to unemployment, domestic violence, school abandonment and their employment. That is why they are obliged to abandon school. Almost all the children that abandon primary education and do not return to school remain illiterate. The presence of 1034 illiterate children in the capital speaks about what the illiteracy, considered as inexistent in Albania, has reappeared now (Office of Social Care, Tirana municipality). The abandonment of school is associated with negative long term effects, thus the phenomenon needs to be estimated properly, in order that measures are taken for the support of special social- educational projects for this Borough.

In 2005-2007, Tirana municipality has financed the opening of the summer schools, in which are integrated even the children that abandon school. In eight schools where it was applied the opening of the summer schools, 204 illiterate children have been identified. "Isa Boletini" school (Borough 11) has the largest number of illiterate children. (76 people, aged 10-20).

The number of illiterate people in Borough 11 is 132 out of which 19 belong to age category of 10, 65 belong to the age category of $11-15,46$ belong to age category $16-20$ and 2 persons of the age category of over 20 years old. Over $85 \%$ of the pupils in Borough 11 are incomers from the northeastern areas, after 1990. Their families bear big socialeconomic problems. During the survey, some of the reasons that were mentioned for not attending school were: economic reasons, mentality, and family reasons. Since 2005, financial facilitating programs have been implemented for children that live in families with little incomes, which attend nurseries and kindergartens of Tirana city, by benefiting a full or partial reduction of the monthly fees for the public nurseries and kindergartens. Through this program, financial support is offered to the families in risk such as; women as heads of the family, girl-mothers, disabled children and families where the head of the family is paralyzed. During 2007, in the nurseries and kindergartens of borough no: 11, 20 children have benefited, 17 in nurseries and 3 in kindergartens, whereas 28 pupils have benefited in schools, out of whom 23 in secondary schools and 5 pupils of high school. Through such projects which are numerous, it is aimed the creation of the alternative models for the completion of the primary education, the elimination of illiteracy in Tirana, by securing the integration of the children in need, children of incomers, Roma and Egyptian children in summer schools.

Chart 2. Number of Illiterate pupils in some schools in Tirana

\begin{tabular}{|c|l|c|c|c|c|c|c|}
\hline \multirow{2}{*}{ School name } & \multirow{2}{*}{ Borough } & \multirow{2}{*}{ No of illiterate people } & Illiterate people & According & To the age category & \\
\cline { 4 - 7 } & & & Up to 10 years old & $11-15$ years old & $16-20$ years old & Over 20 years old \\
\hline 1. & Kolë Jakova & 11 & 47 & 4 & 29 & 12 & 2 \\
\hline 2. & Qazim Turdiu & 11 & 9 & 3 & 2 & 4 & - \\
\hline 3. & Isa Boletini & 11 & 76 & 12 & 34 & 30 & - \\
\hline
\end{tabular}




\begin{tabular}{|c|l|c|c|c|c|c|c|}
\hline 4. & Dhora Leka & 7 & - & - & & - & \\
\hline 5. & Vasil Shanto & 5 & - & - & - & - & - \\
\hline 6. & brahim Brahja & 2 & 10 & - & - & 8 & 2 \\
\hline 7. & Lasgush Poradeci & 6 & 13 & 1 & 5 & 7 & - \\
\hline 8. & Hasan Prishtina & 3 & 49 & 3 & 11 & 34 & 1 \\
\hline & Total & 204 & 23 & 81 & 95 & 5 \\
\hline
\end{tabular}

Source. Regional Education Directorate, Tirana

The problem of the education institutions lack is evaluated by many entrepreneurs as a good investment opportunity in the field. There are many houses here that have turned into nurseries and private schools, such as "11 Janari" college in "Rruga e Durresit" and kindergarten such as "Topoxhixho" kindergarten, "Grerëzat" in "Pandi Dardha" street, "Kristal" kindergarten in "Lord Bajron" street etc. In Borough 11 there is even the Social Center "Don Bosko", vocational and high school which exercises its activity in "Don Bosko" street mainly frequented by pupils coming from various regions of the country. The improvements in the infrastructure of services that are directly linked or not to the population education, serve to the improvement of the situation in the future. Thus, in the territory of this borough, is also the Library no 7, in "Lord Bajron Street. The premises of the Library are in the first floor of a flat. The Library is already functional. Its premises have never been rehabilitated. It is an asset of the Municipality and has a surface of 134, 1 square meters. The premises comprise 5 spacious reading halls, also premises for the books archive. Currently, it has an archive of 4500 books and 228 regular readers. The reading hall is not fully exploited due to the amortization of the supplies. Other additional premises could be created from its rehabilitation, which would serve to cover an archive of 25.000 books.

Borough 11 also holds sports activities organized by "Lapraka Sportive Association" which participates in all the football activities with the age of 10 to 18 and by a decision of the Municipality Council, the football team "Lapraka 11" is being established which is playing in the third category.

"Lapraka" cinema is in the first floor of a flat in the main street. Actually is non functional.

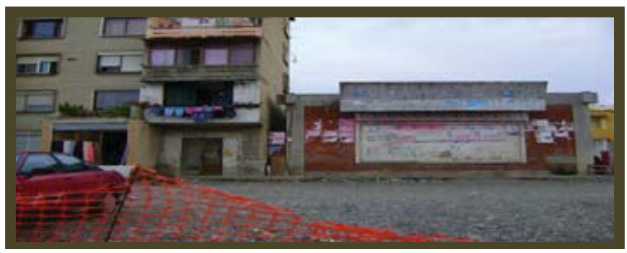

Photo 2. "Lapraka" cinema

The requests for social services for a population with different characteristics and needs are very complex and specific in their kind. There are 59 social centers operating in Tirana out of which, 4 are public and 55 are private and offer services according to problems and specific needs as below;

1. Social center that offers services for children (S.C.C)

2. Social centers offering services for women and children (S.C.W.C)

3. Social centers offering services for the elderly (S.C.E)

4. Social center offering services for the youth (S.C.Y)

5. Social center offering services for disabled people (S.C.D.P)

Chart 3. Social Centers presented in chart according to boroughs

\begin{tabular}{|l|c|c|c|c|c|c|c|c|c|c|c|}
\hline \multirow{2}{*}{ Social Centers } & \multicolumn{10}{|c|}{ Boroughs } \\
\cline { 2 - 15 } & No.1 & No.2 & No.3 & No.4 & No.5 & No.6 & No.7 & No.8 & No.9 & No.10 & No.11 \\
\hline S.C.C & 0 & 4 & 0 & 3 & 4 & 2 & 3 & 0 & 2 & 1 & 1 \\
\hline S.C.W.C & 0 & 1 & 0 & 0 & 3 & 0 & 3 & 0 & 1 & 2 & 0 \\
\hline S.C.E & 0 & 2 & 0 & 0 & 3 & 0 & 3 & 0 & 1 & 1 & 0 \\
\hline S.C.Y & 0 & 4 & 0 & 0 & 3 & 0 & 1 & 0 & 3 & 3 & 0 \\
\hline S.C.D.P & & 1 & & & & 1 & 1 & & 1 & 1 & \\
\hline Total & 0 & 12 & 0 & 3 & 13 & 3 & 11 & 0 & 8 & 8 & 1 \\
\hline
\end{tabular}

Source: Directorate of Social Care, Tirana Municipality, 2010 
The private social centers offer a variety of services which are not distributed equally in the capital, or according to the needs. This has come as a result of the lack of orientation, and also due to their financial capacities for renting. As it is seen in the chart, in Borough 11 there is the Daily Semi-Residential Center for the Street Children which is established in the "Metallic Enterprise" premises in Tirana, covering a surface of 1100 square meters, where the exploited area for the center covers 607 square meters. The daily residential center offers integrating and rehabilitating services for Street Children. 300 children aged 0-18 are treated in the center. The categories of street children that are included here are: Children who beg, children that work, children that may leave school etc. The residential center is always hospitable for abandoned or violated children and accommodates them till an alternative solution is found for their well-being. The services that are offered are: Consultation, education, hygiene, health services, and psycho-social services in cases of serious abuses.

The human potential which is present at the center and mostly evaluated is the young age which is of great interest for a better future. If these people are offered better opportunities, education and work, they will play a considerable role in the future developments.

\section{References}

\section{Surveys}

Tirana Municipality, Forms of the Registry Office

Tirana Municipality, Forms of Statistics Service

Tirana Municipality, Statistical Bulletin 2005, 2006, 2008

Tirana Municipality and UNICEF "Evaluation of needs", 2003

Tirana Municipality and the Directorate of Social Care "Distribution of public and non public social centers in Tirana".

Tirana Municipality and the Directorate of Social Care, "Project on the school abandonment and illiteracy"

Tirana Municipality and the Directorate of Social Care, "Project, secret abandonment"

Karaguni. M , Dumani B , " Demo- Economic and Social Tirana Relief " 2005

INSTAT "Registration of population and houses", April 2001

INSTAT "Maps of poverty and inequality in Albania 2004"

INSTAT "Albanian population in 2001" 